International and Comparative Corporate Law Journal

\author{
Volume 12 • $2017 \bullet$ Issue 2 \\ Special Issue: Daughters of Themis: \\ International Network of Female \\ Business Scholars \\ Editors: Roseanne Russell \\ and Beate Sjåfjell
}

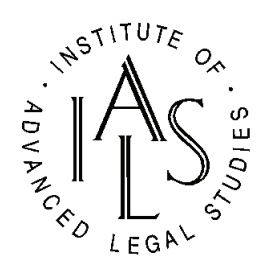

CAMERON

I $\mathrm{MAY}$

INTERNATIONALLAW \&OLICY 
Copyright (C) CMP Publishing

Cameron May is an imprint of CMP Publishing Ltd

Published 2017 by CMP Publishing

UK Email: orders@cmppublishing.com

Website: www.cmppublishing.com

All rights reserved. Except for the quotation of short passages for the purpose of criticism and review, no part of this publication may be reproduced, stored in a retrieval system or transmitted, in any form or by any means, electronic, mechanical, photocopying, recording or otherwise, without prior permission of the publisher.

This journal is sold subject to the condition that it shall not by way of trade or otherwise, be lent, resold, hired out, or otherwise circulated without the publisher's prior consent in any form of binding or cover other than that in which it is published and without a similar condition including this condition being imposed on the subsequent purchaser.

ISSN: $1388-7084$

Printed by Grosvenor Group

To subscribe please contact CMP Publishing Ltd

Annual subscription price (paper) $£ 185.00$ or (Multi User PDF) $£ 350$ 


\title{
HOW DO FTSE100 COMPANIES FRAME GENDER EQUALITY?
}

\author{
Roseanne Russell ${ }^{1}$
}

\section{INTRODUCTION}

'We continue to promote gender diversity and the business case for gender balance in leadership is clear'. ${ }^{2}$

This statement by Standard Life plc, a member of the FTSE100, captures the prevailing corporate view that women can bring a competitive advantage to business. ${ }^{3}$ These benefits are thought to include 'a widened talent pool, increased responsivity to the market, improved corporate governance and better corporate performance'. ${ }^{4}$ As of June 2016, the percentage of women on FTSE100 boards was 26 per cent with female executive directorships at 9.7 per cent and non-executive directorships at 31.4 per cent. ${ }^{5}$ These figures, showing improvement from previous years, appear to endorse a belief in the 'business case' but significant work remains to be done if gender parity is to be achieved. As Sealy, Doldor and Vinnicombe observe, these percentages 'point to steady progress compared to March 2015 but to a relative stagnation of the pace of change since October $2015^{\prime}{ }^{6}$

The merits or otherwise of the business case for boardroom diversity have been substantially critiqued both empirically and normatively. ${ }^{7}$ The

1 Lecturer, Cardiff School of Law and Politics, Cardiff University. Contact: RussellR8@ cardiff.ac.uk

2 Standard Life plc Annual Report and Accounts at 33.

3 See Lord Davies of Abersoch, Women on boards (UK Government, February 2011) where he states at 3 'the business case for increasing the number of women on corporate boards is clear'. For a more detailed discussion of the factors comprising the 'business case' see C. Villiers, 'Achieving gender balance in the boardroom: is it time for legislative action in the UK?' (2010) 30(4) Legal Studies 533 at 543-545. The FTSE 100 is the index of the 100 largest companies whose shares are traded on the London Stock Exchange. The index is reviewed every three months and its composition can therefore change depending on the performance of the respective companies.

4 E. Hickman, 'Boardroom Gender Diversity: A Behavioural Economics Analysis' (2014) 14(2) Journal of Corporate Law Studies 385 at 385.

5 R. Sealy, E. Doldor and S. Vinnicombe, 'The Female FTSE Board Report 2016, Women on Boards: Taking Stock of Where We Are' (Cranfield University School of Management, June 2016) at 1.

6 Ibid.

7 Seminal examples of the extensive literature include K. Campbell and A. MinguezVera, 'Gender Diversity in the Boardroom and Firm Financial Performance' (2008) 83(3) Journal of Business Ethics 435; R. B. Adams and D. Ferreira, 'Women in the boardroom and their impact on governance and performance' (2009) 94(2) Journal of Financial Economics 291; and M. McCann and S. Wheeler, 'Gender Diversity in the FTSE100: The Business Case Claim Explored' (2011) 38(4) Journal of Law and Society 542. 
empirical evidence that more women directors improve firm financial performance or the rigour of corporate governance is mixed at best. ${ }^{8}$ Moreover, the 'demeaning' ${ }^{\prime}$ nature of linking women's advancement instrumentally to corporate value has revealed a less benign interest of the corporate sector in gender equality. For Roberts, 'the growth of a procapitalist and business-oriented feminism over the past several years' ${ }^{\prime 10}$ has resulted in gender equality being less of a 'categorical good' but a tool for economic gain. Elias has similarly argued that the World Economic Forum's discourse on gender and development views 'women's empowerment ... merely as a driver of growth and competitiveness in an uncertain, post-GFC, economic landscape ${ }^{\prime 11}$

This study makes an original contribution to the literature by using framing analysis to interrogate how the FTSE100 companies 'frame' the boardroom diversity debate. In so doing it does not attempt to provide a further critique of the business case. Rather the aim of the study is to understand the factors motivating corporate engagement with gender equality.

The FTSE100 annual reports for 2013/2014 provide an auspicious data set for this research context. While analysing the discussions of only 100 companies provides for a relatively small sample, the FTSE100 is 'the very index against which the recent diversity and business case arguments are framed'. ${ }^{12}$ The timing of the study also proved propitious. The Financial Reporting Council had amended the Corporate Governance Code (applicable to all listed companies) with effect from 1 October 2012 to include a revised principle that 'the search for board candidates should be conducted, and appointments made, on merit, against objective criteria and with due regard for the benefits of diversity on the board, including gender' ${ }^{13}$ Moreover, it was conducted against the backdrop of the then-recent publication of the Davies review of Women on boards ${ }^{14}$ and amidst heightened discussions of the proposal by the EU in November 2012 for a directive on gender balance amongst non-executive directors on corporate boards, and the related debate on whether mandatory

\footnotetext{
McCann and Wheeler ibid at 544 .

Ibid.

A. Roberts, 'Financial Crisis, Financial Firms....and Financial Feminism? The Rise of 'Transnational Business Feminism' and the Necessity of Marxist-Feminist IPE' (2012) 8(2) Socialist Studies 85 at 87.

11 J. Elias, 'Davos Woman to the Rescue of Global Capitalism: Postfeminist Politics and Competitiveness Promotion at the World Economic Forum' (2013) 7 International Political Sociology 152 at 154 .

12 McCann and Wheeler supra $\mathrm{n} 7$ at 544.

13 Financial Reporting Council, Feedback Statement: Gender Diversity on Boards (FRC, London, October 2011) on background to revision of Principle B2.
}

14 Supra $\mathrm{n} 2$. 
quotas for women directors should be endorsed. ${ }^{15}$ This resulted in (often substantial) discussions of gender and boardroom diversity across all FTSE100 companies surveyed.

In exploring the language that companies themselves use to discuss gender equality, this article reveals three dominant ways in which the debate has been 'framed'. First, and perhaps unsurprisingly given the 'business case for diversity' advanced by policy-makers, 'diversity' is valued highly and it is 'diversity' rather than 'equality' that is prominent in the discourse. However, while some companies appear to view 'diversity' as intrinsically positive, it was more common for diversity to be expressed as an instrument to achieve some further business benefit, notably improved customer insight, better understanding of local markets/ communities, and enhanced critical or creative thinking and decisionmaking. Indeed, there were only five instances where considerations of best practice or broader concerns of equity appeared to be reflected in the motivations of companies. This might be explained by the nature of annual reports as a method of communicating the company's (financial) achievements to investors. Moreover, the obligation under section 172 of the UK Companies Act 2006 for directors to act in a way that promotes the success of the company for the benefit of its members as a whole may lead directors to be cautious about stating non-commercial considerations in their annual reports. Two notable exceptions included:

'Diversity is very important to me and critical to the future of corporate Britain. In my view, it makes business more effective and society more equitable... '16

'Our approach to diversity is important to our reputation as a business, too. Societal and regulatory expectations are increasing - especially around gender diversity'. ${ }^{17}$

Second, support for diversity strongly correlated with the frame of 'merit'. In other words when FTSE100 companies engaged in discussions of diversity, this was more often than not framed (or caveated) as a matter of appointing the 'best person for the job'. Third, an emergent theme of 'nurturing talent' was detected. This differed from explicit discussions of resource maximisation framed in the language of making the most of an available talent pool but rather revealed a more nuanced acknowledgement by business about the need to remove barriers to progression and to tackle women's under-representation in male-

15 Proposal for a DIRECTIVE OF THE EUROPEAN PARLIAMENT AND OF THE COUNCIL on improving the gender balance among non-executive directors of companies listed on stock exchanges and related measures (COM/2012/0614 final).

16 Land Securities Group plc 2014 Annual Report per Chairman Dame Alison Carnwath at 53.

17 British American Tobacco plc Annual Report 2013 at 20. 
dominated industries. While it is possible to interpret this third framing device as a cynical way for companies to 'grow talent' organically and thus provide another avenue for resource maximisation, it may equally be read as a symptom of a growing acceptance by companies that 'socially entrenched forms of disadvantage undermine the ability of certain groups to compete on an equal basis ${ }^{18}{ }^{18}$ Corporate institutions are wellplaced to either recreate, or begin to dismantle, patterns of behaviour and organisational norms that build on these historic disadvantages.

The findings from this study have implications for those seeking to further the debate on boardroom diversity not just in the UK but across other jurisdictions. Indeed while the FTSE100 index of the London Stock Exchange is the focus of this study, the companies listed there need not be incorporated in the UK and often operate on an international basis. Critics of the instrumental nature of the debate will find much to support their concerns that sincere equality is eluded or even impeded by a myopic focus on making the 'business case' and treating gender (or indeed other characteristics such as race or nationality) as a further tool for competitive gain. However there are two more positive implications to help set the agenda for further activity in this area. First, this study pinpoints more concretely the reasons why companies value diversity. Reflecting local markets and consumers is a strong motivation. Strategically drawing corporate attention to increasing levels of societal (and therefore consumer) discontent about inequality ${ }^{19}$ might offer enhanced leverage to encourage companies to take these concerns more seriously and adopt a less utilitarian approach. Second and more tentatively, the focus on nurturing women through the 'talent pipeline', training leaders in 'unconscious bias', and exploring barriers to progression suggests that workplace structural barriers to equality are being acknowledged and addressed.

This article proceeds as follows. Part 2 details the methodological approach used in the study and Part 3 provides an analysis of the results. Part 4 discusses the implications of the findings. A brief conclusion follows in Part 5.

\section{METHODOLOGY}

Framing analysis was used to consider how companies frame discussion of boardroom diversity and gender equality in the boardroom in publicly

18 M. Bell, 'Equality and the European Union Constitution' (2004) 33(3) Industrial Law Journal 242 at 247.

19 C. Calhoun, 'Occupy Wall Street in perspective' (2013) 64(1) British Journal of Sociology 26. 
available corporate documentation (typically annual reports). ${ }^{20}$ Van Hulst and Yanow observe that there are three salient features to 'framing': 'naming, selecting and storytelling'. ${ }^{21}$ As they elaborate:

'In naming the features of a situation, policy-relevant actors draw on language that reflects their understanding of it, often naming the policy problem through metaphor...naming in effect selects what should be seen and diverts attention from other features. And at the same time, the aspects singled out in naming the problem cohere through a storytelling manner of presenting the situation'. ${ }^{22}$

Framing, therefore, 'does two kinds of work. It organizes prior knowledge (including that derived from experience) and values held, and it guides emergent action'. ${ }^{23}$ As such it can be seen as a 'contingent, political act' in its choice of what features to highlight in the portrayal of a situation. ${ }^{24}$

The documents analysed in this study comprised the annual reports of all FTSE100 companies $^{25}$ together with certain publicly available sustainability or corporate responsibility reports pertaining to those companies. There is a risk in analysing company documents that there may be a heavy rhetorical element pervading much of the material' ${ }^{\prime 26}$ and they may 'favour obedience to rules of public relations'. ${ }^{27}$ The aim of the research was not, however, to question the legitimacy or otherwise of any claims made or to attempt to verify a company's commitment to boardroom diversity. Rather it was to interrogate how these issues were framed. A further concern was that the material might be largely homogenous. As Moore has observed, the UK 'comply or explain' model of policing corporate governance risks being 'undermined by corporate boards themselves, who are accustomed in many cases to providing perfunctory or "boiler-plate" explanations for non-compliance with

20 For a similar application of this method in the field of political science, see P. Chaney and D. Wincott, 'Envisioning the Third Sector's Welfare Role: Critical Discourse Analysis of 'Post-Devolution' Public Policy in the UK 1998-2012' (2014) 48(7) Social Policy \& Administration 757 at 759.

${ }_{21}$ M. van Hulst and D. Yanow, 'From Policy "Frames" to "Framing": Theorizing a More Dynamic, Political Approach' (2016) 46(1) American Review of Public Administration 92 at 96.

22 Ibid. Emphasis retained.

23 Ibid. at 98.

24 Ibid. at 99.

25 As the constituents of the FTSE100 can shift over time, the analysis is contained to those companies in the FTSE100 at the time of initial data collection in late 2014/early 2015.

26 A. Keay and R. Adamopoulou, 'Shareholder Value and UK Companies: A Positivist Inquiry' (2012) 13(1) European Business Organization Law Review 1 at 14.

27 Ibid. at 13 . 
Code norms' ${ }^{28}$ While similar themes and language were evident in the material, this congruence, particularly around discussions of the 'value of diversity', was an interesting finding in itself.

Electronic (pdf) versions of each company's annual report (and ancillary related documents where relevant) ${ }^{29}$ were collected and analysed. To identify the salient parts of the data in which issues of gender equality in the boardroom and boardroom diversity were discussed, search terms were devised on the basis of words typically used in corporate documentation to denote association with gender equality and/or boardroom diversity. ${ }^{30}$ These were 'women', 'gender' and 'diversity'. The relevant texts were then divided into what Chaney and Wincott describe as 'quasi-sentences' to denote the expression of a single idea. ${ }^{31}$ Thus the statement:

'The search for Board candidates will continue to be conducted, and nominations/ appointments made, with due regard to the benefits of diversity on the Board, however, all appointments to the Board are ultimately based on merit... ${ }^{\prime 32}$

can be 'coded' (or categorised) under the frame of (1) 'value of diversity' ("...with due regard to the benefits of diversity..."); and (2) 'merit' ("all appointments... are ultimately based on merit"). Each 'quasi-sentence' was categorised based on a frame derived from a close reading of the materials and inductive analysis. As Thomas describes it, inductive analysis:

'...refers to approaches that primarily use detailed readings of raw data to derive concepts, themes, or a model through interpretations made from the raw data...'33

Rather than attempting to test out a hypothesis or assumption (and thereby use deductive analysis), it was only through a systematic reading of the annual reports and subsequent coding that themes were identified. Adopting Chaney and Wincott's sequential approach to framing, ${ }^{34}$ further 'sub-frames' were identified. For example, in the 'value

28 M. T. Moore, “Whispering Sweet Nothings": The Limitations of Informal Conformance in UK Corporate Governance' (2009) 9(1) Journal of Corporate Law Studies 95 at 103.

29 Much of the material relating to discussions of gender equality contained in Sustainability or Corporate Responsibility reports extended to discussions of community gender empowerment projects and was not included here as the focus was on the boardroom context. Within that context there was significant repetition between the material found in those reports and that contained in the Annual Report.

30 These searches were conducted using the search function of Adobe Reader software.

31 Chaney and Wincott (2014) supra n 20 at 759.

32 Royal Bank of Scotland Group plc, Annual Report and Accounts 2013 at 51.

33 D. R. Thomas, 'A General Inductive Approach for Analyzing Qualitative Evaluation Data' (2006) 27(2) American Journal of Evaluation 237 at 238.

34 Chaney and Wincott (2014) at 760. 
of diversity' frame these could include 'talent pool', 'customer insight', and 'reflect society' as indicated in the following statement:

'To attract and draw skills from a diverse pool of talent we aim to have an appropriate balance of gender and ethnicity that represents the labour market we are part of and the customer base we serve.'35

To ensure consistency in the author's coding and limit any bias, preliminary categories of 'key themes' were collated from the raw text at the stage of initial data collection. This was carried out independently of the author by two research assistants engaged to collect the material but with reference to the evaluation aims of examining how the issues of gender equality in the boardroom and boardroom diversity were framed..$^{36}$ These initial categories were created from actual phrases used in the texts. Examples of these themes included 'talent pool', 'customer base', and 'better decision-making'. The author then conducted a second categorisation of themes without reference to this primary coding. Both sets of themes were compared to ensure that the coding was reliable. These were further refined to identify the most major themes and subthemes revealed by the texts. All coding was carried out manually allowing an 'intimate interaction' with the material. ${ }^{37}$

\section{ANALYSIS}

Analysis of the relevant material revealed three dominant frames of discussion. Figure 1 shows the percentage of companies discussing gender in the context of each frame. There was unanimous agreement from each company within the FTSE100 of the value of diversity (100 per cent). There was also a considerable correlation between discussions of the value of diversity with the frame of 'merit' (73 per cent). A smaller but still considerable percentage of companies also explicitly framed discussions of diversity in the context of 'nurturing talent'. Here, the use of 'nurturing talent' may be distinguished from considerations of the available talent pool (discussed below and represented in Figure 2). Rather 'nurturing talent' in this context refers to explicit framing by companies of the need to provide deliberate and targeted strategies for development or nurturing of women such as women's networks, shadowing or training. Each theme is discussed in turn below.

35 Severn Trent plc, Annual Report and Accounts 2014 at 24. Emphasis added.

36 Thanks are due to Ishbel MacKenzie and Ella Carroll for their assistance. I am also grateful to the Cardiff University School of Law and Politics Undergraduate Research Assistance programme for the funding that enabled the initial stages of data collection to be completed.

37 A. Ludlow, Privatising Public Prisons: Labour Law and the Public Procurement Process (Oxford: Hart Publishing, 2015) at 57. 


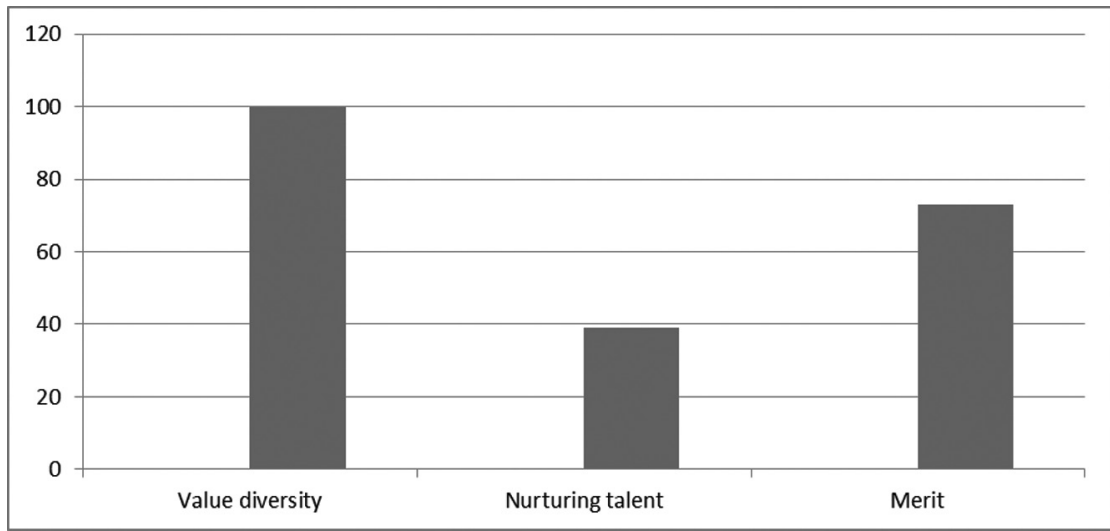

Figure 1: Percentage of companies discussing dominant themes

\subsection{Valuing diversity}

Companies unanimously appeared to acknowledge the value of diversity, sometimes stated as a self-evident truth:

'A diverse and inclusive culture is important for business success'. ${ }^{38}$

'We continue to promote gender diversity and the business case for gender balance in leadership is clear'. ${ }^{39}$

There were also unambiguous links made between gender diversity and achieving a clear commercial advantage:

'We want to lead in our industry by improving gender diversity amongst our senior managers, because research suggests businesses with a better gender balance at this level perform better than their competitors' ${ }^{40}$

'...greater colleague diversity will deliver commercial benefit' ${ }^{41}$

However, diversity considerations also extended to characteristics other than gender:

'...two of the four South African-based Board members are from historicallydisadvantaged communities' ${ }^{2}$

and it was apparent that corporate engagement with diversity was motivated less by concerns about women's representation and more about

Severn Trent plc Annual Report and Accounts 2014 at 23.

Standard Life plc Annual Report and Accounts 2013 at 33.

Lloyds Banking Group plc Responsible Business Report 2013 at 38.

Wm Morrison Supermarkets plc 2013/2014 Corporate Responsibility Review at 71.

Mondi plc CSR Report 2013 at 4. 
diversity of backgrounds, skills, experiences and outlooks particularly in the context of the global nature of many corporate operations:

'One of the most important aspects of my role is to foster the right dynamic on the board to ensure constructive challenge of the executive directors. This involves having directors with the right range and balance of skills, expertise and attributes (including broad diversity of perspective)...' ${ }^{43}$

'As a global organisation with customers spanning a multitude of countries, cultures and professions, we view diversity as a valuable business asset' ${ }^{44}$

To allow for a more sophisticated account of why companies might value diversity, secondary analysis of 'sub-themes' identified a range of factors explicitly stated as justification for valuing diversity. Figure 2 shows the number of companies with explicit discussions of these motivating factors. For some companies a range of factors might be present. The phrase 'Royal Mail employs a diverse mix of people who reflect the communities in which we work, and the customers we serve 45 frames diversity in the context of two sub-themes: 'reflect society' and 'customer insight'. Each was recorded as one example of a motivating factor. The depth of engagement or incidence of certain themes was not recorded. For example, while some companies would make frequent mention of a factor throughout the Annual Report, other companies would only refer to a factor on one occasion. Both instances would be recorded as ' 1 ' as it was the range or presence of these frames that was of interest and not how extensively they were reported by individual companies.

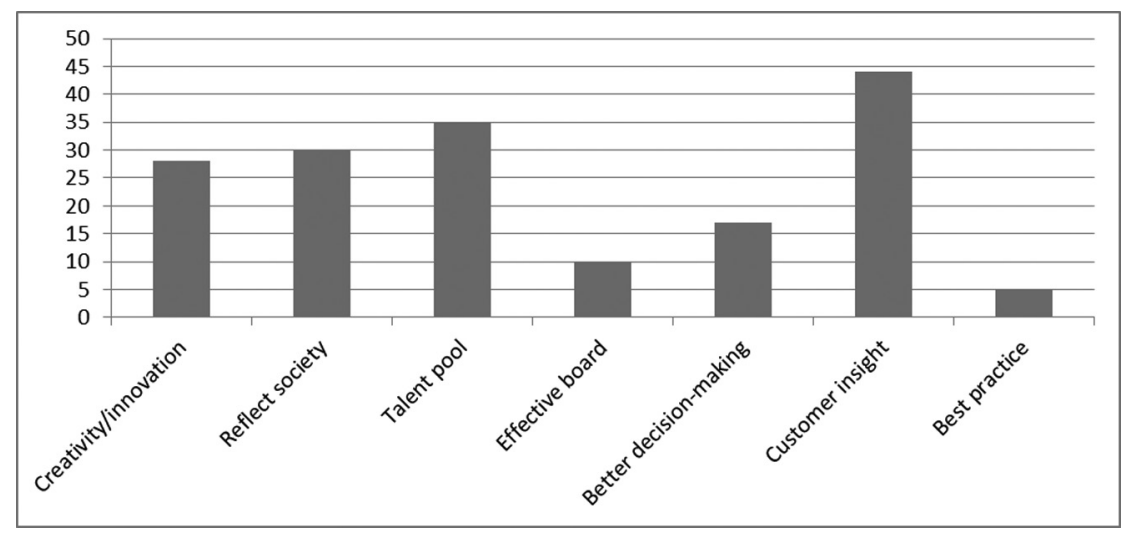

Figure 2: Number of companies who valued diversity with reference to particular sub-themes

43 Johnson Matthey plc 2014 Annual Report and Accounts at 6.

$44 \quad$ Aberdeen Asset Management plc Annual Report and Accounts 2013 at 22.

45 Royal Mail plc Annual Report and Financial Statements 2013-2014 at 34. Emphasis added. 
From a corporate governance perspective it is hoped that a diversity of viewpoints will provide enhanced rigour to corporate decisionmaking. As the UK's Financial Reporting Council noted, 'a lack of gender diversity around the board table may weaken the board by encouraging "group think"'. ${ }^{46}$ Yet, although internal considerations of board effectiveness and enhanced decision-making featured in discussions, external considerations such as customer insight or reflecting society appeared more pronounced suggesting a greater focus on matters of economic advantage. Indeed the commercial advantages of reflecting local markets and consumer bases were often recounted explicitly:

'Women are Unilever's core consumers, controlling nearly two thirds of consumer spending, so it's important that we represent them in our workforce'. ${ }^{47}$

'...the better we reflect our marketplace, the better we can serve it'. ${ }^{8}$

Others highlighted the reciprocal nature of diversity:

'It is our firm belief that having executives and non-executives on the Board that are diverse in age, experience, nationality or gender, provides us with different perspectives. This does not just make good commercial and business sense, but it is good for our colleagues and our customers as well'. ${ }^{49}$

\subsection{Appointing on merit}

The UK's Corporate Governance Code states expressly that 'the search for board candidates should be conducted, and appointments made, on merit... ${ }^{50}$ It would therefore be expected that 'merit' would feature in discussions of board appointments but the extent to which this occurred (in 73 per cent of corporate discussions) and the relatively forcible stance taken in support of 'merit' was of interest. In some cases, gender or other characteristics were given as examples of factors that would not influence those making recruitment decisions:

'Appointments to the Board... are made on merit according to the balance of skills and experience offered by prospective candidates. Whilst acknowledging the

\footnotetext{
Financial Reporting Council (2011) supra n 13 at 4.

Unilever plc Annual Report and Accounts 2013 at 16.

Lloyds Banking Group plc Annual Report and Accounts 2013 at 34.

Travis Perkins plc Annual Report and Accounts 2013 at 84. Emphasis added.

50 Principle B2, The UK Corporate Governance Code (Financial Reporting Council, London, April 2016).
} 
benefits of diversity, individual appointments are made irrespective of personal characteristics such as race, religion or gender'. ${ }^{51}$

'The Board will continue to consider its policy with respect to Board diversity on future appointments but will not place a higher regard on one form of diversity over any other'. ${ }^{52}$

In other cases merit was not referred to explicitly but was implicit in its framing of discussions of diversity such as the use of the phrase 'purposeful diversity': ${ }^{3}$

'...Hargreaves Lansdown will aim to maintain female representation on the board at least at the current level and give due consideration to increasing the level if appropriate candidates are available when board vacancies arise' ${ }^{.54}$

'Subject to securing suitable candidates, when making appointments we will seek directors who fit the skills criteria and gender balance that is in line with the Board's aspiration'. ${ }^{55}$

'During 2013, the committee focused on refreshing the nonexecutive director membership of the Board, seeking to achieve additional diversity in terms of geographical background, experience and gender, subject to any recommended candidates being aligned with the Group's developing strategy and helping to complement the existing skills represented on the Board' ${ }^{56}$

While appointing the best person for the job may seem an obvious and uncontroversial premise, there were examples of where this could inadvertently exclude female candidates.

'It is our firm belief that having executives and non-executives on the Board that are diverse in age, experience, nationality or gender, provides us with different perspectives...In addition, we have a clear preference for non-executives of whatever background, who have demonstrated success as CFOs or CEOs'. ${ }^{57}$

The recent inquiry by the UK's Equality and Human Rights Commission into fairness, transparency and diversity in FTSE350 board appointments found that some role descriptions required candidates to have previous experience of operating in a FTSE board context, which 'risks ruling out suitable candidates from other sectors and could discriminate against

$51 \quad$ Next plc Annual Report and Accounts January 2014 at 36.

52 The Weir Group plc Annual Report and Financial Statements 2013 at 78.

53 Rolls-Royce Holdings plc Annual Report 2013 at 47. Emphasis added.

54 Hargreaves Lansdown plc 2013 Report and Financial Statements at 35. Emphasis added.

55 Vodafone Group plc Annual Report 2014 at 59. Emphasis added.

56 Old Mutual plc Annual Report and Accounts 2013 at 99. Emphasis added.

57 Travis Perkins plc Annual Report and Accounts 2013 at 84. 
candidates from groups that are under-represented on company boards' ${ }^{58}$ Moreover, some roles required "chemistry' or ' $\mathrm{fit}^{\prime}$ with other board members but left these qualities undefined and so open to subjective judgement'. ${ }^{59}$ This strategy was evident in the following quote:

'Due to the complexity of operating in West and Central Africa and the particular experience required, the governance and nomination committee has developed an in depth knowledge of the attributes and character a likely candidate should possess. Therefore during the year the governance and nomination committee did not use an external search agency for this research'. ${ }^{60}$

A further insight into how companies perceived the boardroom diversity debate was found in the clear and resistant stance taken to the question of mandatory quotas. The UK has been steadfast in its rejection of mandatory quotas as the best way to increase boardroom diversity in the domestic context. In a recent five-year review of progress since the publication of the Davies review Women on boards in 2011 it was stated:

'Undoubtedly the setting of realistic, achievable and stretching targets for business has been a key driver of progress. In addition, the voluntary business-led approach which joined all stakeholders together in action has been important... the UK's approach is working' ${ }^{61}$

While fifteen countries have taken the 'controversial' step of adopting quotas, they have not been considered appropriate by UK companies. ${ }^{62}$ The question of whether quotas would be mandated by the EU was, however, a highly topical one during the period in which the annual reports under analysis were being prepared. This may account for the tenor of the discussions regarding appointing on merit and safeguarding the autonomy of corporate actors:

'The Nominations Committee and the Board totally support the principle of appointments - whether at Board level or elsewhere in our organisation - being made on the basis of merit. Neither gender, ethnicity or age are considered to be

58 Equality and Human Rights Commission, An inquiry into fairness, transparency and diversity in FTSE350 board appointments (Manchester: Equality and Human Rights Commission, March 2016) at 10.

$59 \quad$ Ibid.

60 Randgold Resources Limited Annual Report 2013 at 169.

61 Lord Davies of Abersoch, Improving the Gender Balance on British Boards: Women on Boards Davies Review Five Year Summary (UK Government, October 2015).

62 S. Terjesen and R. Sealy, 'Board Gender Quotas: Exploring Ethical Tensions from a Multi-Theoretical Perspective' (2016) 26(1) Business Ethics Quarterly 23 at 24. 
barriers to progress in our Company but neither are they, alone, good reasons to appoint anyone to the Board before they are ready'.63

'The Company values its freedom to retain a group of people who, collectively, have the skills, experience and insight to implement the Company's global vision and objectives and achieve long-term value growth without being hindered by a gender quota which does not take cognisance of the specific situation and culture of the Company'. ${ }^{64}$

'In order to meet the aspiration set out in the 2011 Davies Report 'Women on Boards' that women should make up 25\% of board positions by 2015, we would have to restrict future Board appointments to women only or significantly restructure the size and composition of the Board. We do not regard either of these actions as being in the best interests of the Company'. ${ }^{65}$

\subsection{Nurturing talent}

The third most dominant theme to emerge was one in which boardroom diversity was framed as requiring some form of activity by the company itself to nurture female talent, such as the removal of barriers to progression, training on unconscious bias, or female mentoring. This was particularly evident in companies operating in historically male dominated industries:

'...we recognise that we continue to have a gender imbalance across the Group, especially given that engineering continues to be a predominately male-dominated profession. We acknowledge that we have few women in senior engineering roles but we are committed to building a pipeline of talent up and to that end, I am pleased to report that $26 \%$ of our graduates during 2013 were female...' 66

'Ideally we would like to encourage more locally based women into the mining industry but this is a very challenging area due to a combination of cultural factors. Firstly because women tend to have relatively low labour force participation rates in the generally patriarchal societies of West and Central Africa, and secondly because of the image of mining as a traditionally male dominated industry' ${ }^{67}$

Further initiatives to tackle the under-representation of women and barriers inhibiting their progression to executive appointments included the setting of internal targets and reviewing flexible working policies. While indicative of a more reflective approach to the obstacles to gender balance in the boardroom, it was also clear that the framing of 'diversity' through the lens of 'merit' was pervasive and influenced some of these

63 Fresnillo Plc Annual report 2013 at 130.

64 Reckitt Benckiser Annual Report and Financial Statements 2013 at 25.

65 Tullow Oil plc 2013 Annual Report \& Accounts at 95.

66 Petrofac Limited Annual Report and Accounts 2013 at 81.

67 Randgold Resources Limited Annual Report 2013 at 108. 
more substantive approaches to equality. One example was this account by Mondi plc:

'During 2013 there has been a particular focus on high performing, internationally mobile female employees, and offering targeted support through the Mondi Mentoring Programme'. ${ }^{68}$

While undoubtedly well-intended, restricting such targeted support only to those women who have the potential to be 'internationally mobile' severely limits the pool of women who, due to caring or other obligations, would be able to take advantage of the career benefits that this scheme offers. Moreover, it was apparent that women themselves could view gender-specific programmes intended to nurture their development with suspicion:

'This year, senior women at Tullow, including our non-executive Directors, met to debate the issue of gender diversity within Tullow...Participants agreed that they wanted to achieve career progression on their own merit, and not as a result of specific gender programmes'.69

\section{DISCUSSION}

The analysis of the FTSE100 discourse on gender equality and boardroom diversity reveals that these companies have framed the debate in the context of three clear themes: the value of diversity, the need to appoint on merit, and a more tentative acknowledgement of the need to address structural barriers to progression. By emphasising the value of diversity, gender is viewed (alongside other factors such as nationality, skills and experience) as one other aspect of difference that can offer a competitive advantage. Prügl has observed that the discourse around gender in the aftermath of the financial crisis amounts to an exercise in meaning making via the construction of man' involving redefining women 'as a new Other ${ }^{\prime} \cdot{ }^{70}$ Integral to this meaning-making has been an emphasis on how women differ from men. With purportedly distinctive values, approaches and outlooks women are thought to offer fresh insights to companies and provide some relief to the masculinist cultures implicated in the backdrop to the global financial crisis. Yet by aligning diversity so closely with discussions of the need to appoint on 'merit', it was unclear whether companies wished to emphasise women's presumed differences or focus on providing women (who were as equally talented to men) with

\footnotetext{
Mondi plc, Mondi Group Integrated Report and Financial Statements 2013 at 72.

Tullow Oil plc 2013 Annual Report \& Accounts at 49.

E. Prügl, "'If Lehman Brothers Had Been Lehman Sisters": Gender and Myth in the Aftermath of the Financial Crisis' (2012) 6 International Political Sociology 21 at 21.
} 
the same opportunities. This confusion 'between treating gender as an essentialist category based upon sex and the idea of feminized practises' was similarly observed by McCann and Wheeler. ${ }^{71}$ The problem with the somewhat muddled nature of the discourse is that it is difficult to devise a strategy to foster greater and more sincere corporate engagement with gender equality. In short, should progressive scholars who wish to see a move towards a more sustainable and less shareholder-centric corporate model in which considerations of equality are treated sincerely highlight women's distinctiveness or 'sameness' to men? This question has been the subject of long-standing and intensive debate by feminist scholars and has been criticised as unsatisfactory. For Williams, neither offers a compelling framework to achieve wide-spread structural and organisational change:

'...both take that disadvantage as a given. Sameness arguments do so by asking only that women be allowed to participate in the current discriminatory system in which males have access to gender privilege that women lack: difference arguments do so when they turn evidence of structural disadvantage into evidence of women's 'choice"..$^{72}$

A further problem lies in the dominance of 'merit' as a principle for appointments. While seemingly uncontroversial, it is premised on the idea of equality of treatment, underpinned by the ideal of equality of opportunity for men and women. ${ }^{73}$ This 'presupposes a world inhabited by autonomous individuals making choices' ${ }^{74}$ yet is inadequate to criticise and transform a world in which the distribution of goods is structured along gendered lines' ${ }^{75}$ In the UK the terms of the Equality Act promise equality of treatment when men and women converge at the same metaphorical work-place but ignore entirely that a woman will often face significant structural barriers in getting there. The claim for equality of treatment is necessarily relational ${ }^{76}$ and invariably relates a woman's position to that of a man which ignores the distinctive problems encountered by many women. Treating 'alike with like' as a model of merit requires, obscures the very fact that long-held beliefs about the rightful place of women, conscious and unconscious biases, and a corporate work model based on valuing traits and behaviours more suited to the

$71 \quad$ McCann and Wheeler (2011) supra $\mathrm{n} 7$ at 549.

72 J. Williams, 'Dissolving the Sameness/Difference Debate: A Post-Modern Path Beyond Essentialism in Feminist and Critical Race Theory' (1991) Duke Law Journal 296 at 303304.

73 N. Lacey, 'Legislation against Sex Discrimination: Questions from a Feminist Perspective' (1987) 14(4) Journal of Law and Society 411 at 414.

74 Ibid. at 415 .

75 Ibid.

76 K. T. Bartlett, ‘Gender Law' (1994) 1(1) Duke Journal of Gender Law \& Policy 1 at 2. 
male body make it far less likely that women will be in the position to be appointed on 'merit' compared to men. ${ }^{77}$ Moreover, focussing so heavily on 'merit' and a 'utility-based equality approach' ${ }^{78}$

'requires no admission of previous wrong, no acknowledgement of social injustice or structural discrimination. It focuses instead on the positive contribution that a diverse workforce can have for the institution, its clients and shareholders. In this way, the argument is narrowed, no longer framed by issues of social justice, but reduced to issues of corporate productivity. By focusing on the characteristics of the employee rather the structures that create inequalities, diversity management may contribute to the displacement of struggles to address economic inequality by allowing governments and businesses to claim that they are pursuing equality by recognising diversity, whilst doing nothing to address economic inequality' ${ }^{79}$

In contrast to the frames of 'valuing diversity' and 'merit', 39 per cent of companies appeared to acknowledge problems with this 'current discriminatory system'. ${ }^{80}$ As Squires has noted '...critics inevitably fear that the 'diversity' frame is being used to obscure wider issues of social justice, reducing the scope of equality concerns, de-politicising social relations and containing equality objectives within a utilitarian market model'. ${ }^{81}$ Yet, while it would be naïve to suggest that companies have adopted a remedial model of substantive equality in which historic disadvantages are corrected through positive action (after all nurturing female talent is ultimately part of a long-term strategy to maximise resource) or that social justice is a primary motivation, it would equally be incorrect to suggest that companies are entirely ignorant of more systemic problems of inequality. One example of this is the account by Randgold Resources Limited of the advantages and disadvantages of microfinance operations in the area where the company's Kibali mine is situated:

'For most of the villages around Kibali there are no banks or access to financial credit so it is very hard for an entrepreneurial idea to develop. In such remote areas of Africa there is no magic formula for economic growth, and microfinance is not without its problems. Common issues with microfinance include arbitrary

77 For example, pregnancy discrimination remains a significant problem in the workplace context: Equal Opportunities Commission, Greater Expectations: Summary Final Report - EOC's investigation into pregnancy discrimination (Manchester; EOC, 2005).

78 J. Squires, 'Intersecting Inequalities: Reflecting on the Subjects and Objects of Equality' (2008) 79(1) The Political Quarterly 53 at 59.

79 Ibid.

$80 \quad$ Williams (1991) supra $\mathrm{n} 72$.

81 Squires (2008) supra n 78. 
interest rates, the risk of flooding the market with the same goods and gender bias' $^{\prime} .82$

Serious concerns persist with microfinance and its claims of gender empowerment. Finance (or more accurately a Global North market model of finance) is being deepened 'through projects that aim to financially (and economically) empower women'. ${ }^{83}$ Within this process, the framing of women entrepreneurs as rational economic actors with the propensity of 'saving' the markets 'creates a number of tensions and contradictions that may ultimately do more to re-inscribe than to challenge existing gender power relations ${ }^{\prime}{ }^{84}$ As Rankin notes:

'Engendering development in these ways may indeed harbour some progressive possibilities for women (and could not have occurred without decades of organizing by the Gender and Development (GAD) movement). However, microcredit must also be recognized as a state strategy that constitutes social citizenship and women's needs in a manner consistent with a neoliberal agenda. As such it illustrates clear connections between state power and gender oppression' ${ }^{85}$

The observation by Randgold Limited of the problems with microfinance may be no more than that. However, it does suggest that, as with other corporate discussions about the need to do more to develop women's progression, that there is at least awareness of what is problematic about ongoing, gendered power relations. Despite this apparently more reflective engagement with gender as more than a tool for commercial gain, there is little evidence however of a move away from ultimately regarding gender in utilitarian terms. The 'business case' rhetoric is dominant.

\section{CONCLUSION}

Analysis of FTSE100 documentation reveals that the boardroom diversity is framed by these companies in three distinct ways. The first and most dominant emphasises the 'value of diversity'. The second frames equality through the concept of 'merit': appointments will always be made on merit with the tacit understanding that only those who are 'good enough' will be appointed to executive positions. The third framing device was 'nurturing talent'. This appeared to acknowledge organisational and

82 Randgold Resources Limited Annual Report 2013 at 99.

83 A. Roberts, 'Gender, Financial Deepening and the production of Embodied Finance: Towards a Critical Feminist Analysis' (2015) 29(1) Global Society 107 at 107-108.

84 Ibid. at 108 .

85 K. N. Rankin, 'Governing Development: Neoliberalism, Microcredit, and Rational Economic Woman' (2001) 30(1) Economy and Society 18 at 20. 
structural barriers inhibiting women from reaching their potential but it is unclear whether the primary motivation in stressing the steps that companies are taking to tackle under-representation was driven by sincere engagement with the need to tackle historic disadvantage or whether it was another, albeit long-term, form of resource maximisation.

The findings of this study suggest that considerations of equality and social justice are secondary, or even absent, in the context of an overt commitment to the utilitarian use of 'diversity' to secure economic advantage. The critique of 'diversity' advanced in this article does not deny that there are other grounds of social disadvantage and exclusion, such as race or nationality. Indeed the recent Parker review on ethnic diversity of UK boards has highlighted how little corporate boards reflect the ethnic diversity of the UK population. ${ }^{86}$ What is troubling, however, is the explicit linking of 'diversity' (whether of, for example, race, gender, nationality, sexuality, or social background) with business benefit. While the need to 'nurture talent' provides some openings for a more considered and less instrumental reflection on gender equality, these factors risk being squeezed out in a discourse so heavily influenced by considerations of commercial gain. Interpreting 'gender equality' as a diluted, profit-driven idea of 'diversity' is likely to be inadequate to achieve sincere gender parity in the corporate context.

86 Sir J. Parker, 'A Report into the Ethnic Diversity of UK Boards: "Beyond One by '21"' (2 November 2016). 
Appendix 1 Documents included in Analysis

\begin{tabular}{|c|c|c|}
\hline & Company name & Documents analysed \\
\hline 1 & 3i Group Plc & $\begin{array}{l}\text { Annual Report and Accounts 2014; } \\
\text { Corporate Responsibility } 2014\end{array}$ \\
\hline 2 & $\begin{array}{l}\text { Aberdeen Asset } \\
\text { Management plc }\end{array}$ & Annual Report and Accounts 2013 \\
\hline 3 & Admiral Group plc & Annual Report and Accounts 2013 \\
\hline 4 & Aggreko Plc & Annual Report and Accounts 2013 \\
\hline 5 & Anglo American Plc & Annual Report 2013 \\
\hline 6 & Antofagasta Plc & $\begin{array}{l}\text { Annual Report and Financial } \\
\text { Statements 2013; Sustainability Report } \\
2013\end{array}$ \\
\hline 7 & ARM Holdings plc & $\begin{array}{l}\text { Annual Report 2013: Governance } \\
\text { and Financial Report; Corporate } \\
\text { Responsibility Report } 2013\end{array}$ \\
\hline 8 & Ashtead Group Plc & Annual Report \& Accounts 2014 \\
\hline 9 & $\begin{array}{l}\text { Associated British } \\
\text { Foods plc }\end{array}$ & Annual Report and Accounts 2014 \\
\hline 10 & Astrazeneca Plc & Annual Report 2013 \\
\hline 11 & Aviva Plc & $\begin{array}{l}\text { Annual report and Accounts 2013; Our } \\
\text { Wider Impact Report } 2013\end{array}$ \\
\hline 12 & $\begin{array}{l}\text { Babcock International } \\
\text { Group Plc }\end{array}$ & Annual Report and Accounts 2014 \\
\hline 13 & BAE Systems Plc & Annual Report 2013 \\
\hline 14 & Barclays Plc & Annual Report 2013 \\
\hline 15 & BG Group Plc & $\begin{array}{l}\text { Annual Report and Accounts 2013; } \\
\text { Sustainability Report } 2013\end{array}$ \\
\hline 16 & BHP Billiton Plc & Annual Report 2014 \\
\hline 17 & $\mathrm{BP} P l \mathrm{c}$ & Annual Report 2013 \\
\hline 18 & $\begin{array}{l}\text { British American } \\
\text { Tobacco plc }\end{array}$ & Annual Report 2013 \\
\hline 19 & $\begin{array}{l}\text { British Land Company } \\
\text { plc }\end{array}$ & Annual Report and Accounts 2014 \\
\hline 20 & $\begin{array}{l}\text { British Sky } \\
\text { Broadcasting Group Plc }\end{array}$ & Annual Report 2014 \\
\hline 21 & BT Group Plc & Annual Report 2014 \\
\hline 22 & Bunzl plc & Annual Report 2013 \\
\hline 23 & Burberry Group plc & Annual Report 2013/2014 \\
\hline
\end{tabular}




\begin{tabular}{|c|c|c|}
\hline & Company name & Documents analysed \\
\hline 24 & Capita Plc & Annual report and accounts 2013 \\
\hline 25 & $\begin{array}{l}\text { Carnival Corporation } \\
\& \mathrm{Plc}\end{array}$ & $\begin{array}{l}2013 \text { Annual Report; Strategic Report } \\
\text { and IFRS Financial Statements for } \\
\text { Year Ended November 30, 2013; } 2013 \\
\text { Corporate Sustainability Report }\end{array}$ \\
\hline 26 & Centrica Plc & Annual Report and Accounts 2013 \\
\hline 27 & Coca-cola HBC & $\begin{array}{l}\text { Annual Report 2013; 2013/2014 } \\
\text { Sustainability Report }\end{array}$ \\
\hline 28 & Compass Group PLC & Annual Report 2013 \\
\hline 29 & CRH plc & Annual Report 2013 \\
\hline 30 & Diageo plc & Annual Report 2014 \\
\hline 31 & $\begin{array}{l}\text { Direct Line Insurance } \\
\text { Group plc }\end{array}$ & Annual Report \& Accounts 2013 \\
\hline 32 & Dixons Carphone plc & $\begin{array}{l}\text { Annual Report and Accounts } \\
2013 / 2014\end{array}$ \\
\hline 33 & Easyjet plc & Annual report and accounts 2013 \\
\hline 34 & Experian Plc & $\begin{array}{l}\text { Annual report year ended } 31 \text { March } \\
2014\end{array}$ \\
\hline 35 & Fresnillo Plc & Annual report 2013 \\
\hline 36 & $\begin{array}{l}\text { Friends Life Group } \\
\text { Limited }\end{array}$ & $\begin{array}{l}\text { Annual Report and Accounts } 2014 ; \\
\text { Corporate responsibility report } 2013\end{array}$ \\
\hline 37 & G4S plc & $\begin{array}{l}\text { Annual Report and Accounts 2013; } \\
\text { Corporate Social Responsibility Report } \\
2013\end{array}$ \\
\hline 38 & GKN plc & Annual Report and Accounts 2013 \\
\hline 39 & Glaxosmithkline Plc & Annual Report 2013 \\
\hline 40 & Glencore plc & Annual Report 2013 \\
\hline 41 & Hammerson plc & Annual Report 2013 \\
\hline 42 & $\begin{array}{l}\text { Hargreaves Lansdown } \\
\text { Plc }\end{array}$ & 2013 Report and Financial Statements \\
\hline 43 & HSBC Holdings Plc & $\begin{array}{l}\text { Annual Report and Accounts 2013; } \\
\text { Sustainability Report } 2013\end{array}$ \\
\hline 44 & IMI plc & Annual Report and Accounts 2013 \\
\hline 45 & $\begin{array}{l}\text { Imperial Tobacco } \\
\text { Group Plc }\end{array}$ & Annual Report and Accounts 2013 \\
\hline 46 & $\begin{array}{l}\text { Intercontinental Hotel } \\
\text { Groups Plc }\end{array}$ & Annual Report 2013 \\
\hline 47 & Intertek Group Plc & Annual Report 2013 \\
\hline
\end{tabular}




\begin{tabular}{|c|c|c|}
\hline & Company name & Documents analysed \\
\hline 48 & $\begin{array}{l}\text { International Airlines } \\
\text { Group }\end{array}$ & 2013 Annual Report and Accounts \\
\hline 49 & Intu Properties Plc & Annual Report 2013 \\
\hline 50 & Itv Plc & $\begin{array}{l}\text { Annual Report and Accounts for year } \\
\text { ended } 31 \text { December } 2013\end{array}$ \\
\hline 51 & Johnson Matthey plc & 2014 Annual Report and Accounts \\
\hline 52 & Kingfisher plc & $\begin{array}{l}\text { 2013/2014 Annual Report and } \\
\text { Accounts; Net Positive Report } \\
\text { 2013/2014 }\end{array}$ \\
\hline 53 & $\begin{array}{l}\text { Land Securities Group } \\
\text { plc }\end{array}$ & $\begin{array}{l}2014 \text { Annual Report; Corporate } \\
\text { Responsibility Report } 2014\end{array}$ \\
\hline 54 & $\begin{array}{l}\text { Legal \& General Group } \\
\text { plc }\end{array}$ & $\begin{array}{l}\text { Annual Report and Accounts 2013; } \\
\text { Corporate Responsibility Report } 2013\end{array}$ \\
\hline 55 & $\begin{array}{l}\text { Lloyds Banking Group } \\
\text { plc }\end{array}$ & $\begin{array}{l}\text { Annual Report and Accounts 2013; } \\
\text { Responsible Business Report } 2013\end{array}$ \\
\hline 56 & $\begin{array}{l}\text { London Stock } \\
\text { Exchange Group plc }\end{array}$ & $\begin{array}{l}\text { Annual Report } 31 \text { March 2014; Group } \\
\text { Corporate Responsibility Report } 2014\end{array}$ \\
\hline 57 & $\begin{array}{l}\text { Marks and Spencer } \\
\text { Group plc }\end{array}$ & $\begin{array}{l}\text { Annual report and financial statements } \\
\text { 2014; Plan A Report } 2014\end{array}$ \\
\hline 58 & Meggitt plc & Annual Report and Accounts 2013 \\
\hline 59 & Mondi plc & $\begin{array}{l}\text { Mondi Group Integrated Report and } \\
\text { Financial Statements 2013; CSR Report } \\
2013\end{array}$ \\
\hline 60 & $\begin{array}{l}\text { Wm Morrison } \\
\text { Supermarkets plc }\end{array}$ & $\begin{array}{l}\text { Annual Report and Financial } \\
\text { Statements 2013/2014; 2013/2014 } \\
\text { Corporate Responsibility Review }\end{array}$ \\
\hline 61 & National Grid plc & $\begin{array}{l}\text { Annual Report and Accounts } \\
2013 / 2014\end{array}$ \\
\hline 62 & Next plc & $\begin{array}{l}\text { Annual Report and Accounts January } \\
\text { 2014; Corporate Responsibility Report } \\
\text { to January } 2014\end{array}$ \\
\hline 63 & Old Mutual plc & $\begin{array}{l}\text { Annual Report and Accounts 2013; } \\
\text { Responsible Business Report } 2013\end{array}$ \\
\hline 64 & Pearson plc & Annual Report and Accounts 2013 \\
\hline 65 & Persimmon plc & $\begin{array}{l}\text { Annual Report 2013; Sustainability } \\
\text { Report } 2012\end{array}$ \\
\hline 66 & Petrofac Limited & Annual Report and Accounts 2013 \\
\hline 67 & Prudential plc & Annual Report 2013 \\
\hline
\end{tabular}




\begin{tabular}{|c|c|c|}
\hline & Company name & Documents analysed \\
\hline 68 & $\begin{array}{l}\text { Randgold Resources } \\
\text { Limited }\end{array}$ & Annual Report 2013 \\
\hline 69 & $\begin{array}{l}\text { Reckitt Benckiser } \\
\text { Group plc }\end{array}$ & $\begin{array}{l}\text { Annual Report and Financial } \\
\text { Statements 2013; Sustainability Report } \\
2013\end{array}$ \\
\hline 70 & Reed Elsevier plc & $\begin{array}{l}\text { Annual Report and Financial } \\
\text { Statements 2013; Corporate } \\
\text { Responsibility Report } 2013\end{array}$ \\
\hline 71 & Rio Tinto plc & $\begin{array}{l}2013 \text { Annual Report; } 2013 \text { Sustainable } \\
\text { Development Report } 2013\end{array}$ \\
\hline 72 & $\begin{array}{l}\text { Rolls-Royce Holdings } \\
\text { plc }\end{array}$ & Annual Report 2013 \\
\hline 73 & $\begin{array}{l}\text { Royal Bank of Scotland } \\
\text { Group plc }\end{array}$ & $\begin{array}{l}\text { Annual Report and Accounts 2013; } \\
\text { Sustainability Review } 2013\end{array}$ \\
\hline 74 & Royal Dutch Shell plc & $\begin{array}{l}\text { Annual Report 2013; Sustainability } \\
\text { Report } 2013\end{array}$ \\
\hline 75 & Royal Mail plc & $\begin{array}{l}\text { Annual Report and Financial } \\
\text { Statements 2013-2014; Corporate } \\
\text { Responsibility Report 2013-2014 }\end{array}$ \\
\hline 76 & $\begin{array}{l}\text { RSA Insurance Group } \\
\text { plc }\end{array}$ & $\begin{array}{l}\text { Annual Report and Accounts 2013; } \\
\text { Corporate Responsibility Report } 2013\end{array}$ \\
\hline 77 & SABMiller plc & $\begin{array}{l}\text { Annual Report 2014; Sustainable } \\
\text { Development Summary Report } 2014\end{array}$ \\
\hline 78 & The Sage Group plc & Annual Report and Accounts 2013 \\
\hline 79 & J Sainsbury plc & $\begin{array}{l}\text { Annual Report and Financial } \\
\text { Statements 2014; 20x20 November } \\
2013\end{array}$ \\
\hline 80 & Schroders plc & $\begin{array}{l}\text { Annual Report and Accounts 2013; } \\
\text { Corporate Responsibility Report } 2013\end{array}$ \\
\hline 81 & Severn Trent plc & Annual Report and Accounts 2014 \\
\hline 82 & Shire plc & $\begin{array}{l}\text { Annual Report 2013; Responsibility } \\
\text { Matters September } 2014\end{array}$ \\
\hline 83 & Smith \& Nephew plc & $\begin{array}{l}\text { Annual Report 2013; Sustainability } \\
\text { Report } 2013\end{array}$ \\
\hline 84 & Smiths Group plc & $\begin{array}{l}\text { Annual Report 2014; Corporate } \\
\text { Responsibility Report } 2014\end{array}$ \\
\hline 85 & $\begin{array}{l}\text { Sports Direct } \\
\text { International plc }\end{array}$ & Annual Report 2014 \\
\hline 86 & SSE plc & Annual Report 2014 \\
\hline
\end{tabular}




\begin{tabular}{|c|c|c|}
\hline & Company name & Documents analysed \\
\hline 87 & St. James's Place plc & Annual Report \& Accounts 2013 \\
\hline 88 & Standard Chartered plc & $\begin{array}{l}\text { Annual Report 2013; Sustainability } \\
\text { Review } 2013\end{array}$ \\
\hline 89 & Standard Life plc & $\begin{array}{l}\text { Annual Report and Accounts 2013; } \\
\text { Sustainability Report } 2013\end{array}$ \\
\hline 90 & Tesco plc & $\begin{array}{l}\text { Annual Report and Financial } \\
\text { Statements 2014; Tesco and Society } \\
\text { Report } 2014\end{array}$ \\
\hline 91 & Travis Perkins plc & Annual Report and Accounts 2013 \\
\hline 92 & TUI Travel plc & $\begin{array}{l}\text { Annual Report and Accounts for Year } \\
\text { Ended } 30 \text { September 2013; Sustainable } \\
\text { Holidays Report } 2013\end{array}$ \\
\hline 93 & Tullow Oil plc & $\begin{array}{l}2013 \text { Annual Report \& Accounts; } 2013 \\
\text { Corporate Responsibility Report }\end{array}$ \\
\hline 94 & Unilever plc & $\begin{array}{l}\text { Annual Report and Accounts 2013; } \\
\text { Sustainable Living Plan } 2013\end{array}$ \\
\hline 95 & $\begin{array}{l}\text { United Utilities } \\
\text { Group plc }\end{array}$ & $\begin{array}{l}\text { Annual Report and Financial } \\
\text { Statements for year ended } 31 \text { March } \\
\text { 2014; Corporate Responsibility Full } \\
\text { Report } 2014\end{array}$ \\
\hline 96 & Vodafone Group plc & $\begin{array}{l}\text { Annual Report 2014; Sustainability } \\
\text { Report 2013/2014 }\end{array}$ \\
\hline 97 & The Weir Group plc & $\begin{array}{l}\text { Annual Report and Financial } \\
\text { Statements } 2013\end{array}$ \\
\hline 98 & Whitbread plc & $\begin{array}{l}\text { Annual Report and Accounts } \\
\text { 2013/2014; Corporate Responsibility } \\
\text { Report 2012/2013 }\end{array}$ \\
\hline 99 & Wolseley plc & Annual Report and Accounts 2014 \\
\hline 100 & WPP plc & $\begin{array}{l}\text { Annual Report \& Accounts 2013; } \\
\text { Sustainability Report 2013/2014 }\end{array}$ \\
\hline
\end{tabular}

